RESIDENT

\& FELLOW

SECTION

Section Editor

Mitchell S.V. Elkind,

MD, MS

Antonetta Margaretha

Gezina Sas, MD

Fop van Kooten, $\mathrm{PhD}$

Address correspondence and reprint requests to Dr. F. van Kooten, Department of Neurology, Erasmus Medical Centre, PO Box 2040, 3000 CA Rotterdam, The Netherlands f.vankooten@erasmusmc.nl

\title{
Teaching NeuroImages: Sinus pericranii
}

An 18-year-old woman was referred for a slowly growing tumor on her scalp, which had been present since her birth. Examination revealed a soft-tissue non-pulsating mass on her scalp (figure 1) which became larger in recumbent position and with Valsalva maneuver. CT showed that almost the entire venous system drained through enlarged parietal foramina with dilated emissary veins connected to multiple subcutaneous veins, which is called sinus pericranii (SP) (figure 2). Generally, SP is located frontally in
Figure 2 CT scan without ( $A$ and $B$ ) and with contrast ( $C$ and $D)$ just beneath $(A$ and $C)$ and just above ( $B$ and $D$ ) the skull
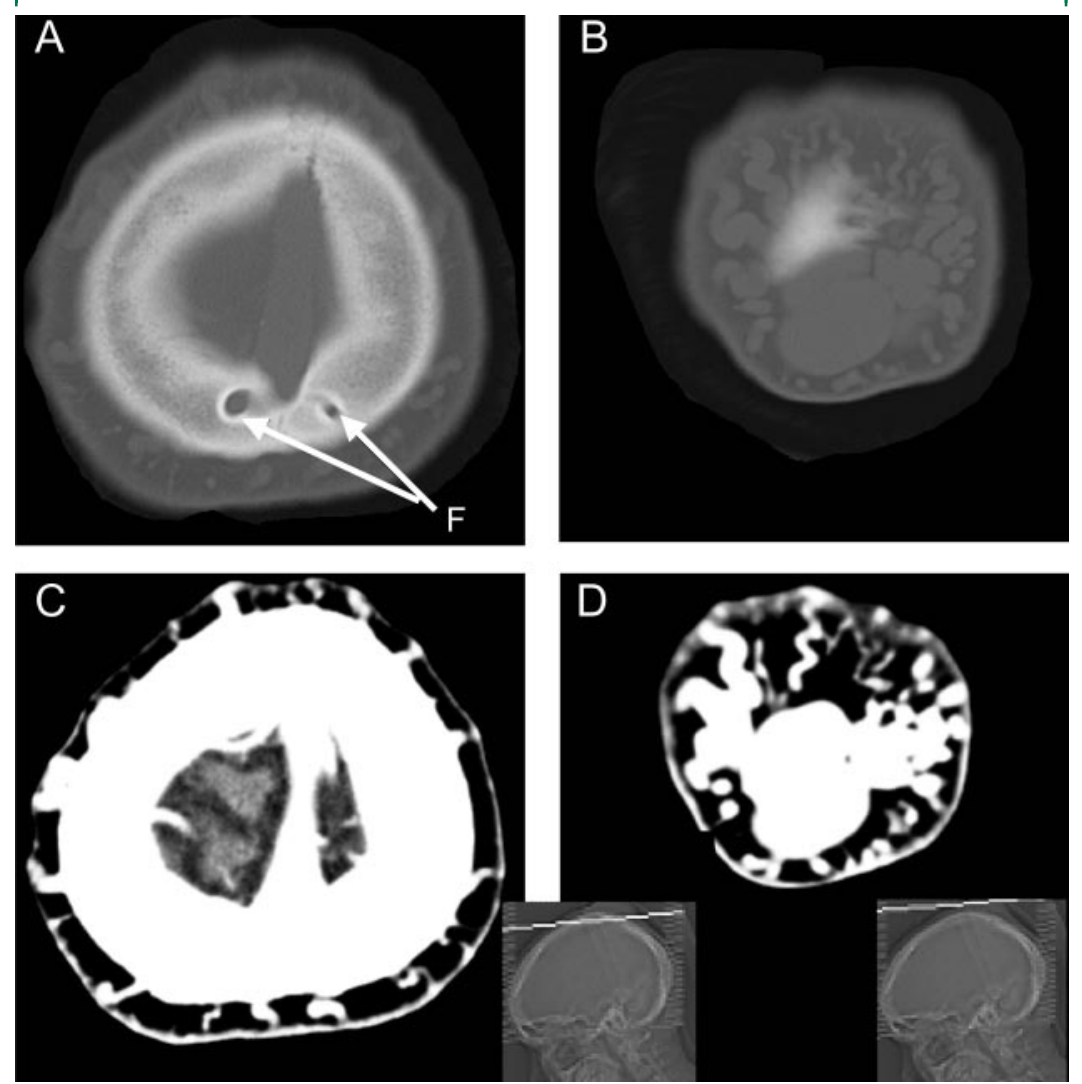

$C T$ scan without ( $A$ and $B$ ) and with contrast ( $C$ and $D$ ) with axial slices intracranially just under $(A$ and $C$ ) and extracranially just above $(B$ and $D$ ) the skull through the tumor, showing bilateral enlarged parietal foramina (F) with dilated emissary veins and the varicosity of the tumor. Not shown here, but visible on CT, were hypoplasia of the falx, bilateral small transverse and sigmoid sinuses, and small jugular foramina with minimally developed jugular veins.

\section{Figure 1 Skull $x$-ray showing the tumor $(T)$ in the parieto-occipital region of the skull}

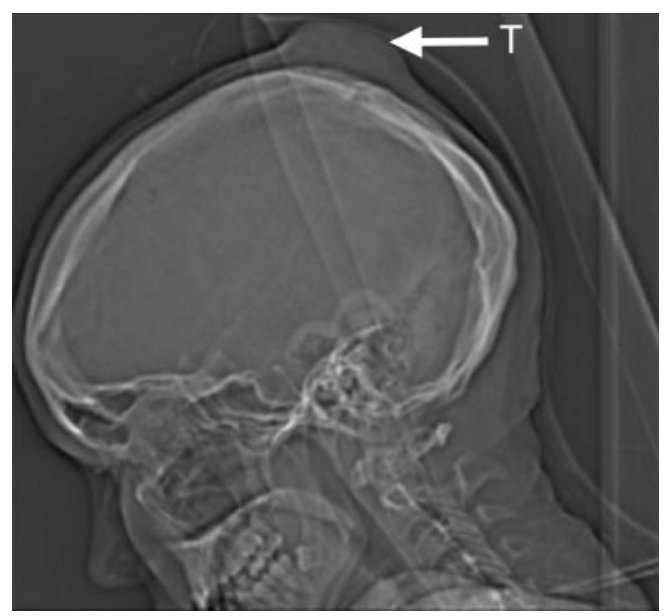

the midline and connected with the superior sagittal sinus. SP is commonly asymptomatic, and classified as dominant if the major venous flow is through the SP and accessory if it concerns a minor part of the venous flow. The prognosis is nearly always good with a low risk of bleeding. Only accessory SPs can be treated safely by surgical intervention or endovascular embolization. ${ }^{1,2}$ Treatment is not recommended for dominant SP and we did not recommend treatment in this case.

\section{REFERENCES}

1. Gandolfo C, Krings T, Alvarez H, et al. Sinus pericranii: diagnostic and therapeutic considerations in 15 patients. Neuroradiology 2007;49:505-514.

2. Kaido T, Kim YK, Ueda K. Diagnostic and therapeutic considerations for sinus pericranii. J Clin Neurosci 2006; 13:788-792. 


\title{
Neurology
}

\author{
Teaching NeuroImages: Sinus pericranii \\ Antonetta Margaretha Gezina Sas and Fop van Kooten \\ Neurology 2009;72; 66 \\ DOI 10.1212/01.wnl.0000345672.15367.dc
}

This information is current as of April 6, 2009

\section{Updated Information \& Services}

References

Citations

Subspecialty Collections

Permissions \& Licensing

Reprints including high resolution figures, can be found at: http://n.neurology.org/content/72/14/e66.full

This article cites 2 articles, 0 of which you can access for free at: http://n.neurology.org/content/72/14/e66.full\#ref-list-1

This article has been cited by 1 HighWire-hosted articles: http://n.neurology.org/content/72/14/e66.full\#\#otherarticles

This article, along with others on similar topics, appears in the following collection(s):

All Clinical Neurology

http://n.neurology.org/cgi/collection/all_clinical_neurology

Arteriovenous malformation

http://n.neurology.org/cgi/collection/arteriovenous_malformation CT

http://n.neurology.org/cgi/collection/ct

Information about reproducing this article in parts (figures,tables) or in its entirety can be found online at:

http://www.neurology.org/about/about_the_journal\#permissions

Information about ordering reprints can be found online: http://n.neurology.org/subscribers/advertise

Neurology ${ }^{\circledR}$ is the official journal of the American Academy of Neurology. Published continuously since 1951, it is now a weekly with 48 issues per year. Copyright . All rights reserved. Print ISSN: 0028-3878. Online ISSN: 1526-632X.

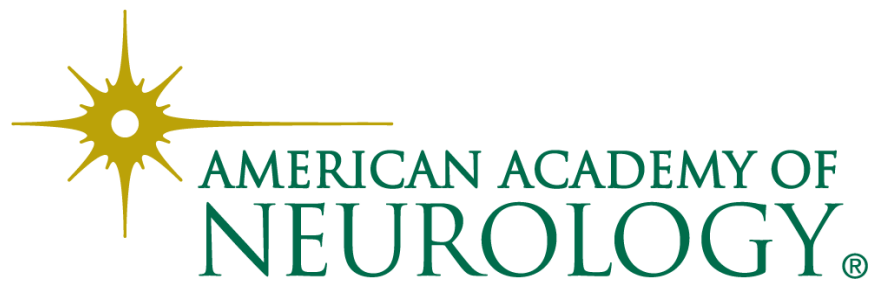

